\title{
Perspectives on Salutogenesis of Scholars Writing in Norwegian
}

\author{
Torill Bull, Geir Arild Espnes, Anita Nordsteien, and Lidia Santora
}

\section{Introduction}

Salutogenesis emerged as a term and a topic in the Norwegian language literature in the late 1990s. One of the first mentions of salutogenesis was, maybe surprisingly, within the field of medicine. Malterud and Hollnagel (1997) took up the concept in a paper advocating a reorientation from risk to resources for general practitioners. Soon after, Grøholt, Sommerschild, and Gjærum (1998) introduced salutogenesis in a book on coping with a focus on professionals' meetings with children, youth, and parents. Over the years that have followed, salutogenesis has been addressed to an increasing degree, suggesting that the perspective is gaining ground in Norwegian research. The number of publications identified from 2011 to 2012 alone is higher than the entire production between 1997 and 2010 .

The literature can be sorted according to at least two criteria, the first being publication format and the second being the centrality of salutogenesis in the publication. The reference list at the end of this chapter includes publications of all types, regardless of how they would be classified

T. Bull $(\bowtie)$

Department of Health Promotion and Development, Faculty of

Psychology, University of Bergen, Bergen, Norway

e-mail: torill.bull@iuh.uib.no

G.A. Espnes

NTNU Center for Health Promotion Research, Norwegian University of Science and Technology, Trondheim, Norway

e-mail: geirae@svt.ntnu.no

A. Nordsteien

Oslo and Akershus University College, Academic Librarian, Buskerud and Vestfold University College, Kongsberg, Norway

e-mail: anita.nordsteien@hbv.no

L. Santora

Center of Health Promotion Research and Department of Social Work and Health Science, Norwegian University of Science and Technology, Trondheim, Norway

e-mail: lidia.santora@svt.ntnu.no according these two criteria. However, for inclusion in the text part of this chapter, we restrict the focus to publications that mention the word salutogenesis more than merely in the passing, in various ways dedicating more room to salutogenic thinking. These publications mention important concepts from the salutogenic model of health, such as generalized resistance resources and the sense of coherence. Still, the centrality of salutogenesis in these publications varies. When it comes to format, research articles, books, and book chapters are of clear interest, but quality publications of other formats (reports and similar) are also included to provide the reader with a good overview. Master's theses are not included.

The literature search was conducted using the Norwegian search engine Oria for publications in Norwegian academic libraries, CRISTIN (Current Research Information System in Norway), and NORA (Norwegian Open Research Archives). The Nordic databases Norart, Idunn, and SveMed+, and the international databases PubMed, EMBASE, CINAHL, and Web of Science, were searched. In all these resources, the truncated term salutogen* was used, with Norwegian language as the only limitation. In the following, we give a very brief overview of the Norwegian language literature that takes a salutogenic perspective. The space limitations of this chapter makes it impossible to do justice to the material in the publications; however, our aim is to give the reader a chance to identify publications of interest that can be accessed for more thorough study.

\section{Health Professions}

A series of publications have argued for the salutogenic perspective within various health-related professions. Within the medical profession, Malterud has been a leading figure in advocating for the perspective in general practice (Malterud, 2001; Malterud \& Hollnagel, 1997; Walseth \& Malterud, 2004), whereas Tellnes $(2007,2008)$ discusses the 
salutogenic perspective in relation to social medicine and public health.

Within the nursing profession, an edited book from 2012 includes two chapters which are relevant in this context. Gammersvik (2012) includes the perspective in a chapter on health promotion in nursing, whereas Larsen (2012) takes a salutogenic perspective in a chapter on the health concept in health promotion. In journal articles, Langeland (2012a) explores the role of salutogenesis in nursing, and Haddeland and Söderhamn (2013) focus on the experiences of nursing students. In 2014, a new book on health promotion in municipality health services was launched (Haugan \& Rannestad, 2014) with a number of chapters where salutogenesis is the main theoretical departure point.

Other professional perspectives within the healthrelated fields are presented in Simensen (2013) writing about environmental therapy, whereas Johannesen and colleagues focus on advisory work mostly related to children and adolescents (Johannessen, Kokkersvold, \& Vedeler, 2010).

\section{Patient Groups}

Salutogenic literature related to particular patient groups has mostly been focused around mental health, much through the work of Langeland (2000) and Langeland \& Vårdal (2014). Gonzalez (2013) writes about the use of gardening for individuals with clinical depression, whereas Varre, Slettebö, and Ruland (2011) describe coping as experienced by cancer patients. Heggdal (2008) focuses on patients, generally, seeing the patient as the expert of own healthpromoting processes through 'the creation of body knowledge' (kroppskunnskaping).

\section{Occupational Health}

One part of the Norwegian language literature focus on salutogenic work life, with a particular focus on job presence as opposed to job absenteeism. With an empirical approach using qualitative methods, one paper explores the role of sense of coherence in relation to job presence for employees with musculoskeletal health complaints (Geving, Torp, Hagen, \& Vinje, 2011), whereas Vinje and Ausland (2013) focus on the health-promoting effects of salutogenic presence at work. Vinje and Ausland also present this topic in four web-based publications focusing on seniors in work life (Ausland \& Vinje, 2012a, 2012b; Vinje \& Ausland, 2012a, 2012b).

\section{Population Groups}

A few population groups have received particular attention. Flatval and Malterud (2009) and Bjørkman (2012) write about health-promoting experiences and coping strategies of lesbians. Øien et al. (2009) write about coping and health-related quality of life among adolescents in senior high school. Also, the elderly receive some focus: Narum and Bergland (2009) write about quality of life and experiences of flow as described by elderly ladies, whereas Jaastad (2011) writes about the salutogenic impact of culture for the elderly. Højdahl (2013) focuses on criminal ward, describing a therapeutic conversation approach to coping and behavior change.

\section{Other Topic Areas}

Self-help and self-help groups are the focus in Hedlund and Landstad (2011), relating the topic to health policies, empowerment, and positive health. As previously mentioned, Langeland $(2000,2011)$ includes a focus on salutogenic groups in mental health care. Moving from disempowerment to empowerment related to reporting of sexual abuse is the focus of a doctoral dissertation (Vea, 2012), whereas project organization related to children is the focus of Midkiff (2012). Reports from the Norwegian University of Science and Technology promote best practice in public health in municipalities in Trøndelag county with foci on alcohol abuse (Lillefjell, Oldervoll, Jakobsen, Thoen, \& Krokstad, 2011) and health and quality of life (Lillefjell, Maass, \& Espnes, 2013). Sletteland and Donovan (2012) focus on salutogenesis in relation to health-promoting local communities. Just before the end of the editing of this book, a Norwegian version of the Hitchhiker's Guide to Salutogenesis was published (Erikssson \& Lindström, 2015).

\section{Final Comments}

Which approach does the literature mainly take? Only a limited number of papers take an empirical quantitative approach measuring the sense of coherence (e.g., Gonzalez, 2013; Langeland, 2009; Lillefjell et al., 2013; Øien et al., 2009). More publications take a qualitative empirical approach (e.g., Flatval \& Malterud, 2009; Geving et al., 2011; Hedlund \& Landstad, 2011; Højdahl, 2013; Narum \& Bergland, 2009; Varre et al., 2011; Vinje \& Ausland, 2013). However, the overwhelming majority of the papers 
seem to apply salutogenesis in a conceptual way, laying out the salutogenic model and relating it to various professions and activities as a theoretical perspective.

Open Access This chapter is distributed under the terms of the Creative Commons Attribution-Noncommercial 2.5 License (http:// creativecommons.org/licenses/by-nc/2.5/) which permits any noncommercial use, distribution, and reproduction in any medium, provided the original author(s) and source are credited.

The images or other third party material in this chapter are included in the work's Creative Commons license, unless indicated otherwise in the credit line; if such material is not included in the work's Creative Commons license and the respective action is not permitted by statutory regulation, users will need to obtain permission from the license holder to duplicate, adapt or reproduce the material.

\section{References}

Ausland, L. H., \& Vinje, H. F. (2012a). Eldre ledere har funnet balansen og onsker å fremme narvar. Retrieved November 3, 2015, from http://seniorpolitikk.no/fakta/forskning/forskning_2.

Ausland, L. H., \& Vinje, H. F. (2012b). Helsens dynamikk på arbeidsplassen: Betraktninger fra en studie om seniorers narvaer og velvare $i$ arbeidslivet. Retrieved November 3, 2015, from http:// seniorpolitikk.no/fakta/forskning/forskning_2.

Bjørkman, M. (2012). Lesbisk selvtillit—lesbisk helse: Utfordringer og mestringsstrategier hos lesbiske kvinner. Doctoral thesis, Universitetet i Bergen, Bergen. Retrieved November 3, 2015, from https://bora.uib.no/handle/1956/5996.

Erikssson, M., \& Lindström, B. (2015). Haikerens guide til salutogenese. Oslo: Gyldendal.

Flatval, M., \& Malterud, K. (2009). Helsefremmende erfaringer hos lesbiske. Tidsskrift for Den norske legeforening, 129(23), 2476-2478.

Gammersvik, A. (2012). Helsefremmende arbeid i sykepleie. In T. Larsen \& Å. Gammersvik (Eds.), Helsefremmende sykepleie: I teori og praksis (pp. 99-119). Bergen: Fagbokforlaget.

Geving, G., Torp, S., Hagen, S., \& Vinje, H. F. (2011). "Sense of coherence"-en faktor av betydning for helse og jobbnærvær? Scandinavian Journal of Organizational Psychology, 3(2), 32-45.

Gonzalez, M. T. (2013). Betydningen av terapeutisk hagebruk ved klinisk depresjon: En prospektiv studie i et eksistensielt perspektiv. Tidsskrift for psykisk helsearbeid, 10(2), 138-148.

Grøholt, B., Sommerschild, H., \& Gjærum, B. (Eds.). (1998). Mestring som mulighet i mote med barn, ungdom og foreldre. Oslo: Tano Aschehoug.

Haddeland, K., \& Söderhamn, U. (2013). Sykepleierstudenters opplevelse av veiledningssituasjoner med sykepleiere i sykehuspraksis: En fenomenologisk studie. Nordisk sygeplejeforskning, 3(1), 18-32.

Haugan, G., \& Rannestad, T. (2014). Helsefremming i kommunehelsetjenesten. Oslo: Cappelen Damm Forlag.

Hedlund, M., \& Landstad, B. (2011). Forskning på selvhjelp og selvhjelpsgrupper: Helsepolitikk, empowerment og positiv helse. Retrieved November 3, 2015, from http://hdl.handle.net/11250/ 146109.

Heggdal, K. (2008). Kroppskunnskaping: Pasienten som ekspert $i$ helsefremmende prosesser. Oslo: Gyldendal akademisk.

Højdahl, T. (2013). Samtaler om uønsket atferd og endring: "BaMsamtalen". Retrieved November 3, 2015, from http://hdl.handle.net/ $11250 / 160557$.
Jaastad, L. (2011). Kulturdeltakelse og helse: Den kulturelle spaserstokken, arena for kulturell deltakelse for seniorer $i$ Trondheim kommune. Retrieved November 3, from http://www. ntnu.no/documents/12446710/16798533/Kulturdeltakelse+og + Helse.pdf

Johannessen, E., Kokkersvold, E., \& Vedeler, L. (2010). Rådgivning: Tradisjoner, teoretiske perspektiver og praksis (3rd ed.). Oslo: Gyldendal akademisk.

Langeland, E. (2000). Samtale om hverdagen: Erfaringer fra en samtalegruppe for personer med psykiske lidelser med fokus på salutogenese. Bergen: Høgskolen i Bergen.

Langeland, E. (2004). Fra patogenese til salutogenese: En redegjørelse av kunnskap og refleksjoner som kan begrunne behandling av psykiske helseproblemer innenfor et salutogent paradigme. In G. O. Hole \& T. T. T. Sudmann (Eds.), Vitenskapsteoretiske refleksjoner: Essaysamling (pp. 171-193). Bergen: Høgskolen i Bergen.

Langeland, E. (2006). Mestring av psykiske helseproblemer: Salutogenese i teori og praksis. In A. Almvik, L. Borge, \& R. A. Berntsen (Eds.), Psykisk helsearbeid $i$ nye sko (pp. 87-103). Bergen: Fagbokforlaget.

Langeland, E. (2007). Mestring av psykisk helseproblemer: Rehabilitering av hjemmeboende personer med psykisk helseproblemer-en intervensjonsstudie $\mathrm{i}$ grupper med fokus på salutogenese. In E. Gjengedal \& B. R. Hanestad (Eds.), A leve med kronisk sykdom: En varig kursendring (2nd ed., pp. 355-371). Oslo: Cappelen akademisk forlag.

Langeland, E. (2009). Betydningen av en salutogen tilnærming for å fremme psykisk helse. Sykepleien Forskning, 4(4), 288-296. doi:10. 4220/sykepleienf.2009.0143.

Langeland, E. (2011). Salutogene samtalegrupper: En arena for $\emptyset \mathrm{kt}$ mestring og velvære. In A. Lerdal \& M. S. Fagermoen (Eds.), Laring og mestring: Et helsefremmende perspektiv i praksis og forskning (pp. 208-235). Oslo: Gyldendal akademisk.

Langeland, E. (2012a). Betydningen av den salutogene modell for sykepleie. Klinisk Sygepleje, 26(2), 38-48.

Langeland, E. (2012b). Salutogenese som forståelsesramme i psykisk helsearbeid. In T. Larsen \& $\AA$. Gammersvik (Eds.), Helsefremmende sykepleie: I teori og praksis (pp. 195-216). Bergen: Fagbokforlaget.

Langeland, E., \& Vårdal, J. (2014). Betydningen av kunnskapen om salutogenese for psykisk helsearbeid. In A. Almvik \& L. Borge (Eds.), Å sette farger på livet: Helhetlig psykisk helsearbeid. Fagbokforlaget: Bergen.

Larsen, T. (2012). Helsebegrepet i helsefremmende arbeid. In T. Larsen \& A. Gammersvik (Eds.), Helsefremmende sykepleie: I teori og praksis (pp. 45-56). Bergen: Fagbokforlaget.

Lillefjell, M., Maass, R., \& Espnes, G. A. (2013). Helse og livskvalitet $i$ Malvik kommune 2012 - LEV VEL. Retrieved November 3, 2015, from http://www.ntnu.no/documents/12446710/16798533/Rap port_LEV+VEL.pdf/b8e99639-bf09-4e75-8a36-e1ccef2e0c21.

Lillefjell, M., Oldervoll, L. M., Jakobsen, K., Thoen, H., \& Krokstad, S. (2011). Alkoholbruk i Stjørdal kommune —n kunnskapsoversikt. Retrieved November 3, 2015, from http://www.ntnu.no/documents/ 12446710/16798533/Alkoholbruk+i+Stj\%C3\%B8rdal+kommune +-+En+kunnskapsoversikt.pdf.

Malterud, K. (2001). Kan allmennlegen være healer? Om medisinske tradisjoner, lege-pasient-forholdet, salutogenese og empowerment. Tradisjon, 31(2), 77-83.

Malterud, K., \& Hollnagel, H. (1997). Fra risikojakt til ressursmobilisering-fra teori til allmennpraksis. Nordisk Medicin, 112(8), 288-291. 
Midkiff, A. (2012). Med barn som prosjekt: Prosjektorganisering —et verktøy for samarbeid: En oppfølgingsstudie. Asker: Brusetkollen skole og ressurssenter.

Narum, I., \& Bergland, A. (2009). Livskvalitet og salutogenese. Tidsskrift for psykisk helsearbeid, 6(2), 100-109.

Øien, I., Langeland, E., \& Natvig, G. K. (2009). Mestring og helserelatert livskvalitet blant ungdom i videregående skole. Norsk tidsskrift for sykepleieforskning, 11(3), 41-50.

Simensen, H. (2013). Aktiviteter i en miljøterapeutisk kontekst. Tidsskriftet Norges barnevern, 90(2), 100-109.

Sletteland, N., \& Donovan, R. M. (2012). Helsefremmende lokalsamfunn. Oslo: Gyldendal Akademisk.

Tellnes, G. (2007). Salutogenese—hva er det? Michael, 4(2), 144-149.

Tellnes, G. (2008). Salutogenese. In Ø. Larsen, A. Alvik, K. Hagestad, \& M. Nylenna (Eds.), Samfunnsmedisin (pp. 455-459). Oslo: Gyldendal akademisk.

Varre, P., Slettebö, Å., \& Ruland, C. (2011). "Det er mitt liv det gjelder". Kreftpasienters beskrivelse av mestringsmuligheter, slik det kommer til uttrykk på et internettbasert diskusjonsforum. Vård $i$ Norden, 31(3), 4-8.

Vea, H. (2012). Fra avmakt til makt i eget liv: Anmeldelse av seksuelle overgrep og helse. Doctoral thesis, Nordic School of Public Health, Göteborg.

Vinje, H. F., \& Ausland, L. H. (2012a). Kollegafellesskap som fremmer narvar og velvare i seniorers arbeidsliv. Retrieved November 3, 2015, from http://seniorpolitikk.no/fakta/forskning/forskning_2.

Vinje, H. F., \& Ausland, L. H. (2012b). Narvar i seniorers arbeidsliv: Presentasjon av en kvalitativ studie. Retrieved November 3, 2015, from http://seniorpolitikk.no/fakta/forskning/forskning_2.

Vinje, H. F., \& Ausland, L. H. (2013). Salutogent nærvær bygger helsefremmende arbeidsliv. Socialmedicinsk Tidsskrift, 90(6), 810-820.

Walseth, L. T., \& Malterud, K. (2004). Salutogenese og empowerment i allmennmedisinsk perspektiv. Tidsskrift for Den norske legeforening, 124(1), 65-66. 